\title{
Is there a motherhood penalty in retirement income in Europe? The role of lifecourse and institutional characteristics
}

\author{
KATJA MÖHRING*
}

\begin{abstract}
This study examines the retirement income of women in Europe, focusing on the effect of motherhood. Due to their more interrupted working careers compared to non-mothers and fathers, mothers are likely to accumulate fewer pension entitlements, and consequently, to receive lower incomes in later life. However, pension systems in Europe vary widely in the degree to which they compensate for carerelated career interruptions by means of redistributive elements or pension care entitlements. Therefore, care interruptions may matter for the retirement income of women in some countries, but may be rather irrelevant in others. On the basis of life history data from the Survey of Health, Ageing and Retirement in Europe (SHARELIFE) for women aged between 60 and 75 years in 13 European countries, the interplay of individual lifecourse characteristics with institutional and structural factors is examined. The results show that the lower retirement income of mothers is mainly a result of fewer years in employment and lower-status jobs throughout the lifecourse. The analysis of institutional factors reveals that pension care entitlements are not able to provide a compensation for care-related cutbacks in working life. A generally redistributive design of the pension system including basic or targeted pension schemes, in contrast, appears as an effective measure to balance differences in employment participation over the lifecourse.
\end{abstract}

$\boldsymbol{K E Y}$ WORDS-employment history, retirement income, motherhood, pension systems, lifecourse, SHARELIFE.

\section{Introduction}

In most European countries exists a significant gender gap in retirement income (Burkevica et al. 2015; Tinios, Bettio and Betti 2015). The main reason for the lower retirement income of women is that they shoulder the main burden of care responsibilities throughout their lifecourses (Ginn, Daly and Street 2001). Previous research on the wage penalty to

* Department of Sociology, University of Mannheim, Germany. 
motherhood has shown that child-care responsibilities are associated with career interruptions, lower earnings and lower-status occupations (Budig and England 2001; Dotti Sani 2015; Gash 2009; Waldfogel 1997). According to the assumption of cumulative disadvantage over the lifecourse, this wage penalty is likely to perpetuate into old age, leading to a reduction in the later retirement income of mothers compared to women without children (Crystal and Shea 1990; Crystal, Shea and Reyes 2016; Dewilde 2003). Therefore, this study examines the gap in retirement income due to motherhood that might stem from factors related to two areas. First, mothers differ from non-mothers in their typical lifecourse configurations: they have usually shorter durations in employment over their lifecourse, and have a higher probability of working part-time and in lower-status jobs (Abendroth, Huffman and Treas 2014; Gash 2009). Furthermore, they are likely to be in marriages with a traditional labour arrangement and to place reliance on their husbands' pension income instead of investing in their own. Therefore, the first range of explanatory factors for the possible gap in retirement income is related to individual lifecourse developments. Second, women with care responsibilities - despite generally increasing rates of maternal employment - do not fulfil the norm of a continuous career in standard employment, which is still the benchmark for achieving a sufficient public pension income in the pension systems of most European countries (Leisering 2003; Leitner 2001). However, pension systems in Europe vary widely in the degree to which they compensate for carerelated career interruptions by means of redistributive elements or pension care entitlements. Due to these differences, care interruptions may matter for the retirement income of women in some countries, but may be rather irrelevant in others.

Previous research on women's retirement income mainly focuses on a few selected countries such as the United Kingdom and Germany (Dewilde 2012; Evandrou and Glaser 2003; Fasang, Aisenbrey and Schömann 2013; Frommert, Heien and Loose 2013; Sefton et al. 2011). Hence, the effects of institutional characteristics have been analysed only with regard to these specific countries. This study, therefore, aims to explore whether and why motherhood is associated with lower incomes in later life for a broader set of countries with diverse institutional arrangements and female lifecourse structures. Individual life history data come from SHARELIFE - the third wave of the Survey of Health, Ageing and Retirement in Europe (SHARE) - for 13 European countries (BörschSupan, Brandt and Schröder 2013; Schröder 201 1). ${ }^{1}$ With regard to institutional and structural factors, I focus on the extent to which national pension systems balance interrupted careers and the degree of gender inequality in working life. For the former dimension, a new indicator is developed to 


\section{$25^{62}$ Katja Möhring}

measure the generosity of pension care entitlements. The empirical analysis proceeds in two steps: first, I analyse individual-level impact factors of women's retirement income related to care-giving, and the employment and marital history; second, I examine how country-level characteristics moderate these individual-level effects. To my knowledge, this is the first study that examines the impact of motherhood on retirement income, combining the analysis of individual lifecourse and country-level impact factors for a large set of countries.

The article is organised as follows: the next section outlines results from previous research on the individual and institutional determinants of women's retirement income. On this basis, hypotheses for the empirical analysis are derived. The third section informs the reader about the data source, the sample, the operationalisation of the micro- and macrovariables, and provides details on the applied regression techniques. The results are presented in the following section, and in the last section, I conclude and describe the implications as well as the limitations of the study.

\section{Theory and previous research}

Previous research shows that mothers on average face higher barriers to achieving consistent careers and a high occupational status, and are more likely to work in part-time jobs compared to childless women (Abendroth, Huffman and Treas 2014; Gash 2009). Following the assumption of cumulative (dis)advantage in lifecourse research, inequalities in the early or midcareer phase will persist or even intensify over the lifecourse and accumulate as a motherhood penalty in terms of lifetime earnings and final retirement income (Crystal and Shea 1990; Crystal, Shea and Reyes 2016; Dewilde 2003). However, the effect of lifecourse characteristics on outcomes in later life is dependent on the context and historical time (Elder, Kirkpatrick Johnson and Crosnoe 2003). Welfare state institutions play a key role here as they may compensate for disadvantages arising from care responsibilities in two possible ways: first, through creating favourable conditions for female employment and labour market participation of mothers (Budig, Misra and Boeckmann 2012; Lewis 2010); and second, through installing redistributive elements in national pension systems that work in favour of those with incomplete contribution histories (Leitner 2001; Möhring 2015). In this section, I will first expand on factors related to women's lifecourse and motherhood that may influence their retirement income and then describe what role institutional and structural factors play in compensating or intensifying these individual lifecourse factors. 


\section{Individual level: lifecourse determinants}

Previous research on the motherhood wage penalty in midlife shows that motherhood and care-related career interruptions lead to a reduction in the level of subsequent earnings that goes beyond the direct effect of reduced working hours and persists even after women have completely returned to full employment (Budig and England 2001; Waldfogel 1997). However, regarding the question of whether and how these disadvantages translate into old age, i.e. how lifecourse factors influence women's retirement income, previous results are inconsistent and highly dependent on the countries selected. Dewilde (2012) finds a negative effect for the number of children on the retirement income of both men and women in Belgium, but not in the United Kingdom. On the contrary, Sefton, Evandrou and Falkingham (2011) report a small negative effect of motherhood on the individual income of older women in Britain. Fasang, Aisenbrey and Schömann (2013) also find a negative relationship between the number of children and retired women's income in Britain, but not in Germany, and this effect is cancelled out when the duration of marriage is controlled for. The authors conclude that the negative effect of motherhood in Britain might stem from the traditional division of labour within married couples rather than representing a general motherhood penalty in retirement income. The results of Frommert, Heien and Loose (2013) for Germany again differ, showing that child care has a negative impact on the pension income of women, especially if it is related to long periods of employment interruption or part-time work. To sum up, it is likely that mothers do not achieve lower retirement incomes per se, but rather as a consequence of disadvantages in previous labour market participation. Also, the negative effect of motherhood may partly arise from pursuing traditional role models within marriage, rather than directly from having children. Accordingly, it can be assumed that the motherhood penalty in retirement income vanishes when employment and marital history characteristics are controlled for. These considerations lead me to the formulation of the following two hypotheses:

- Hypothesis 1: The more children a woman has, the lower her retirement income will be.

- Hypothesis 2: Considering factors related to employment and marital histories will reduce the gap in retirement income between mothers and non-mothers.

Previous studies on the wage penalty for motherhood have shown that the negative effect persists even after controlling for career and job characteristics as well as unobserved heterogeneity (Waldfogel 1997). Besides lower 


\section{${ }_{25}^{64}$ Katja Möhring}

working hours or lower-status jobs, differences in wages and bonus payments play a role: mothers may achieve fewer promotions and pay rises during their careers, and, as a consequence lower life-time earnings than non-mothers. Therefore, even if mothers combine child care and paid work, they may achieve fewer entitlements in earnings-related pension systems than non-mothers. Accordingly, I add the following hypothesis on the interaction effect of motherhood and employment:

- Hypothesis 3: Mothers benefit less from being employed throughout the lifecourse than non-mothers.

\section{Country level: institutional and structural determinants}

As described above, institutional and structural characteristics from two areas are relevant for women's retirement income: first, women's possibilities to acquire pension rights and to accumulate savings during their working life despite care responsibilities; and second, how pension systems deal with non-standard employment histories typical for mothers with parental leave periods. The first type of policy aims to avoid disadvantages $a$ priori through enabling mothers to combine care and work, and to accumulate pension entitlements from their own employment. Policies and regulations embedded in national pension systems, in contrast, may compensate ex post for labour market disadvantages faced by mothers in their previous career through scaling up insufficient entitlements (Leisering 2003). These two types of policy are not mutually exclusive: in fact, most countries inhibit some form of work-family policies in order to foster maternal employment as well as redistributive elements in the pension system to compensate for absences due to care provision. However, countries differ in the relative weight they put on either of these policy strategies. In this section, I will elaborate on relevant countrylevel factors, starting with regulations within national pension systems, followed by aspects of gender equality in working life and mothers' opportunities to participate in paid work.

\section{The pension system}

As the vast majority of European pensioners is dependent on public pensions, the design of national pension systems has a large impact on their financial wellbeing (Organisation for Economic Co-operation and Development (OECD) 2015). The rules and regulations inherent in national pension systems are related to normative assumptions about lifecourses, employment relationships and gender roles. This is most evident in the fact that the majority of European pension systems define the ideal 
of an uninterrupted career in standard full-time employment as the benchmark in their pension calculation, and as a result, discriminate against those with care-related interruptions (Frericks, Maier and de Graaf 2007; Leisering 2003; Leitner 2001). However, countries in Europe vary in how strong the link of contributions and benefits is in the national pension system. The concept of pension tiers serves to assess the situation of individuals with non-standard careers. Based on this concept, pension benefits are differentiated according to the degree to which they are dependent on their previous employment history and/or personal savings. The first tier comprises pensions that are not dependent on the working history and are either universal or means-tested; the second tier consists of earningsrelated pensions that link the benefit level to individuals' previous contributions and duration of employment (mostly defined-benefit); finally, defined-contribution pensions into an individual account constitute the third tier (Immergut and Anderson 2009; Möhring 2015). Individuals with non-standard careers have the most favourable position in systems with a high relevance of the first tier, while they are disadvantaged in systems in which the second tier provides the main income. This applies even more to private defined-contribution pension schemes of the third tier because these require steady investment throughout the lifecourse and mostly do not compensate for periods without contributions (OECD 2015).

Based on the concept of pension tiers, a first important characteristic of pension systems to assess the situation of individuals with non-standard careers is the existence and design of redistributive elements in the first tier and their relative importance vis-à-vis the second tier. Against this background, two main types of pension system in Europe can be distinguished. While in the majority of European pension systems, earnings-related pension benefits of the second tier are predominant, in some European countries, such as the Netherlands and Denmark, basic pensions with a flat-rate benefit for the whole residential population of the first pension tier are the main source of pension income. The latter are mostly multipillar systems that comprise a basic pension and mandatory or - due to the high coverage-quasi-mandatory occupational pension schemes (Ebbinghaus and Neugschwender 2011). In countries with predominantly public earnings-related pensions, the coverage of occupational pension schemes is typically much lower. Table 1 includes a short description of the overall design of national pension systems and the types of first tier scheme. Historically, multi-pillar universal pension systems have mostly evolved in Northern European countries with a traditionally high female labour market participation, whereas countries with a dominant earningsrelated tier mostly also feature lower rates of female employment. However, the Netherlands represents an exception with a universal 
T A B L E 1. Overview of national pension systems (situation in 20o6)

\begin{tabular}{ll}
\hline Country & General structure and first-tier design \\
\hline Austria & Earnings-related public scheme with targeted pension \\
Belgium & Earnings-related public scheme with minimum pension \\
Czech Republic & Public pension scheme with basic and earnings-related pension \\
Denmark & Multi-pillar system with public basic pension scheme \\
France & Multi-pillar system with targeted pension \\
Germany & Earnings-related public scheme, social assistance safety net \\
Italy & Earnings-related public scheme, social assistance safety net \\
Poland & Earnings-related public scheme with minimum pension \\
Spain & Earnings-related public scheme with minimum pension \\
Sweden & Earnings-related public scheme with targeted pension \\
Switzerland & Multi-pillar system with targeted pension \\
The Netherlands & Multi-pillar system with public basic pension scheme \\
\hline
\end{tabular}

Sources: Organisation for Economic Co-operation and Development (OECD) (2009, 2015); Queisser and Whitehouse (2006).

pension system and only low to medium female employment rates throughout the 2oth century (Visser 2002).

Besides this general structure of the pension system, further redistributive elements that are integrated in the second earnings-related tier are relevant for mothers with interrupted contribution histories. Leitner (2001) points out that the minimum number of contribution years required to be eligible for pension benefits is crucial: if pension benefits are only granted for those with long contributory histories, mothers with parental leave periods are disadvantaged. Furthermore, pension care entitlements are important for mothers' retirement income. These entitlements are granted for parenthood and periods of care leave and aim to compensate for income loss due to career interruptions in earnings-related pension systems (Burkevica et al. 2015; Horstmann and Hüllsman 2009). Finally, the general generosity of pension benefits plays a role as especially those with few entitlements and savings as a consequence of interrupted employment histories will suffer from insufficient public pension benefits (OECD 2015). Based on these considerations, four elements of national pension systems can be identified as being of high relevance for the compensation of non-standard and interrupted careers: (a) the general degree of redistribution in the pension system as indicated by the design of the first tier; (b) the minimum number of contribution years to be eligible for public pension benefits; (c) the design of pension care entitlements integrated in the second tier; and (d) the overall generosity of pension benefits in the first and second tier.

Redistribution. The design and the relevance of the first pension tier show how much a country's pension system redistributes in favour of those with 
incomplete careers. Three different types of first tier design can be distinguished in addition to systems without a first tier: basic, targeted and minimum pensions. According to Queisser and Whitehouse (2006), a pension system is most redistributive if it comprises a universal basic pension scheme without requirements related to employment history. These schemes are typically residence-based. Targeted pension schemes are similar, however, they are means-tested. A lower degree of redistribution is present in minimum pension schemes, which additionally require a minimum number of contribution years in the earnings-related scheme of the second tier. The least redistributive are national pension systems without specific first-tier pensions. Here retirees have to rely on general social assistance schemes that are characterised by a typically more restricted eligibility and lower benefits (OECD 2015; Queisser and Whitehouse 2006).

Minimum contribution years. All national pension systems in Europe, apart from the residence-based Dutch and Danish basic pension schemes, require a minimum number of contributory years before citizens are eligible for public pension benefits. The necessary period of contributions varies between three months in France to be eligible for a partial pension and 25 years in Austria and the Czech Republic (US Social Security Administration 2014). Systems requiring long contribution histories will discriminate against mothers with unsteady working careers (Leitner 2001 ).

Pension care entitlements. Specific entitlements to credit parenthood and child care are integrated in the second tier of all predominantly earningsrelated national pension systems in Europe. These entitlements are granted for parenthood and/or periods of child care and aim to compensate for care-related career interruptions through improving the recognition of such non-contributory periods (Horstmann and Hüllsman 2oog). The design of pension care entitlements varies between countries not only with regard to the level of these entitlements, but also whether they are universal for all parents or dependent on further requirements (see Appendix Table A2). For example, if care entitlements are only granted for care leave periods, they might produce incentives for long employment interruptions or even complete withdrawal that are then adverse for mothers' retirement income in the long run. However, it is unlikely that the long-term prospect of a certain pension benefit does have an effect on women's employment behaviour when they are younger (Haan and Thiemann 2015). In some countries, pension care entitlements are further accompanied by regulations aimed at upgrading reduced contributions from part-time employment as result of care obligations. 


\section{Katja Möhring}

Consequently, depending on their actual design, pension care entitlements may in fact compensate for mothers' lower pension contributions due to interrupted employment histories or part-time work. However, the existence and generosity of pension care entitlements does not necessarily indicate how strongly the pension system as a whole redistributes in favour of persons with care-related career interruptions. Care entitlements are increasingly important the more the pension system is earnings-related, while they are not required in pension systems that comprise universal residence-based benefits, as in the Netherlands or Denmark.

Generosity and coverage of public and private pensions. Private insurances or savings schemes typically have a much lower coverage among women compared to men and among lower-income compared to higher-income groups (Bettio, Tinios and Betti 2013). These groups are therefore more dependent on sufficient public pension benefits to achieve an adequate living standard in old age. Especially individuals with incomplete contribution histories, such as mothers with parental leave periods, are negatively affected if pensions are privatised and responsibility for later-life income is individualised. However, mandatory and quasi-mandatory occupational schemes differ from that: as they have a high coverage of all groups of the workforce including part-time employees, they may benefit mothers' pension income (Ebbinghaus and Neugschwender 2011).

These considerations on the role of pension systems for women's retirement income can be summarised in the following hypotheses:

- Hypothesis 4a: The more the national pension systems balance interrupted careers through a high degree of general redistribution, low eligibility requirements, pension care entitlements, a high general generosity of pension benefits and private provision organised as mandatory or quasi-mandatory occupational rather than voluntary personal pension schemes, the smaller the motherhood penalty in retirement income will be.

- Hypothesis $4 \mathrm{~b}$ : Among these characteristics of pension systems, the general degree of redistribution will be most relevant for the compensation of the motherhood penalty in the retirement income.

\section{Gender equality in the labour market and maternal employment}

In addition to the pension system, labour market and family policies have an impact on the motherhood penalty in retirement income. As research on the wage penalty on motherhood in mid-life has shown, gender inequality in the labour market and work-family policies that support the 
reconciliation of work and child care are crucial factors affecting women's employment opportunities (Boeckmann, Misra and Budig 2015; Dotti Sani 2015; Gash 2009). For the later retirement income, policies that support the equal participation in paid work of men and women and the employment possibilities for mothers are important because they influence women's chances to accumulate pension entitlements and savings throughout the lifecourse. Indeed, previous research for Britain and Germany has shown that policies fostering female employment, like public day-care, are more beneficial for their later retirement income than policies focused on income compensation for families, such as child allowances (Fasang, Aisenbrey and Schömann 2013). For the birth cohorts of women who are now in retirement, it is not the current state of family policies which is important, but rather the development of women's possibilities to participate in the labour market throughout the second half of the 2oth century. These have been influenced by the expansion of welfare states and economic development, especially with regard to the formation of the service sector, and by the presence of traditional gender norms. Countries with an early expansion of welfare services and the public service sector provide more possibilities for female employment than largely rural or industrial countries (Möhring 2016). Furthermore, the strength of the male breadwinner model in a country influences women's employment chances, especially with respect to the possibilities for combining care and paid work (Lewis 1992). Accordingly, a final hypothesis is formulated on the impact of lifecourse-relevant policies on women's retirement income:

- Hypothesis 5: The lower the level of gender inequality in the labour market and the higher the employment participation of mothers has been in a country, the smaller the motherhood penalty in retirement income will be.

Figure 1 illustrates the hypotheses for the individual and institutional characteristics and their impact on women's retirement income.

\section{Data and methods}

The empirical analysis is based on data from the SHARE Waves 1 and 2 (2006/o7, Release 2.6.o) and employment and family history information from SHARELIFE (Wave 3, 2008/o9, Release 1; Börsch-Supan, Brandt and Schröder 2013; Schröder 2011). SHARELIFE comprises information on employment and family histories. The analysis sample consists of 5,231 women who were not active in the labour force and who were aged 




Figure 1. Theoretical framework and hypotheses.

Note: $\mathrm{H}_{1}-\mathrm{H}_{5}$ : Hypotheses ${ }_{1-5}$. Dashed lines represent hypotheses on interaction effects.

between 6o and 75 years old at the time of the interview, hence born between 1929 and 1947, and reaching retirement age throughout the 1990 and 200os. The sample comprises Austria, Belgium, Czech Republic, Denmark, France, Germany (East), Germany (West), Italy, The Netherlands, Poland, Spain, Sweden and Switzerland.

\section{Operationalisation of individual-level variables}

The dependent variable of the empirical analysis is women's individual annual net income including statutory, occupational and private pension benefits, widow pensions, and social assistance payments. In line with previous research, the dependent variable is denoted as 'retirement income' as the main income source of the sample members are pension benefits (Fasang, Aisenbrey and Schömann 2013). Incomes are adjusted with the purchasing power parity and logarithmised with values of zero set to the minimum income in the sample. The multiple imputations provided by SHARE are used and analysed with the Stata mi-module (Christelis 2011; Stata Corp. 2011).

The main individual-level explanatory variable is the number of children, where values higher than six have been recoded to six (this applies to 1.3 per cent of women in the sample). The individual employment history is described with three variables: the total number of years a woman was employed between ages 25 and 59; thereof the percentage share of 
part-time employment; and a woman's occupational status operationalised on the basis of the International Socio-Economic Index of Occupational Status (ISEI; Ganzeboom and Treiman 1996). The two-digit ISEI code of each job was summarised to the mean over the career prior to retirement and set to zero for women who were never employed. Marital history is described with the sum of years a woman was married between ages 25 and 59. The lifecourse factors span the period from 1954, when the oldest sample members were 25 years old, to 2006, when the youngest members became 59 years old.

As control, a variable indicating marital status at the time of the interview (remarried, divorced, widowed or never married; married as reference category) and a dummy variable for the birth cohorts 1929-39 are included. Furthermore, educational status is operationalised according to the International Standard Classification of Education (ISCED) in three categories: ISCED levels $\mathrm{O}-2$ indicates a low, levels $3-4$ a medium and levels $5^{-6}$ a high educational level. Appendix Table A1 includes the sample statistics for all individual-level explanatory variables.

\section{Operationalisation of country-level indicators}

Redistribution in the pension system. In order to operationalise the degree of redistribution of national pension systems, I rely on a classification provided by Queisser and Whitehouse (2006) that addresses the design of the first pension tier. Universal basic pension schemes are classified as most redistributive, followed by targeted pension schemes with an income test. Firsttier pension schemes that additionally require a minimum number of contribution years ('minimum pensions') are less redistributive followed by pension systems without a non-earnings-related tier (Queisser and Whitehouse 2006). The more redistributive the design of the first pension tier is, the higher is the indicator for redistribution in the pension system.

Minimum contribution years. The sources for the minimum contribution years in national pension systems include Leitner (2001), OECD (2015) and the US Social Security Administration (2014). The values refer to the number of years of contributions to an earnings-related public pension scheme that are necessary to be eligible for benefits. Denmark and the Netherlands are assigned the value of zero as their main pension schemes are residence-based. For some countries, such as France and Switzerland, individuals are entitled to partial pensions after a very low number of required contribution years. Where applicable, these values were taken into account. 


\section{Katja Möhring}

Pension care entitlements. In order to operationalise the design of pension care entitlements, a new indicator is developed based on an assessment of the four dimensions of universality, calculation method, level and upgrading of part-time employment (see the detailed description in the Appendix and Appendix Table A2). The higher the values of this indicator are, the more extensive compensation the systems provide for motherhood, meaning that their eligibility is universal for all mothers and their value equals or comes close to contributions from paid employment.

Pension replacement rate. This indicator is provided by the OECD (2009) and reflects the generosity of public pension benefits, also including mandatory and quasi-mandatory occupational pension schemes. It represents the retirement income of a 'median earner', who had average earnings over a full working career, as a percentage of their previous earnings.

Relevance of occupational and personal pension schemes. This indicator is calculated based on information on the coverage of various types of occupational and personal pension schemes from the OECD (2009). National pension systems were first allocated to four groups: (a) systems with a generally low coverage (below $15 \%$ ) of occupational or personal pensions (Austria, Spain, France, Italy); (b) systems with a high significance of voluntary occupational and/or personal pensions (Belgium, Czech Republic, Germany); (c) countries with mandatory or quasi-mandatory occupational schemes (Switzerland, Denmark, The Netherlands, Sweden); (d) countries with mandatory or quasi-mandatory personal schemes (Poland). ${ }^{2}$ These categories were then summarised into a binary variable indicating whether a country has a high coverage of mandatory or quasi-mandatory occupational schemes.

Labour market - female and maternal employment. In order to operationalise the degree of gender equality on the labour market and mothers' employment chances, two indicators based on SHARELIFE data are generated. The advantage of this procedure is that these indicators refer to the timespan between 1954 and 2006 that is of relevance for the birth cohorts considered in this study. The indicator on female employment is calculated with women's employment rate as a percentage share of men's employment rate. A similar indicator on maternal employment is calculated relating the maternal employment rate to the employment rate of non-mothers. For both indicators higher values reflect higher female and maternal employment, respectively. Table 2 includes an overview of all country-level indicators along with the sample mean value of the dependent variable and a brief description of the national pension system. 
T A B L E 2. Country means of the dependent variable and values of macro-indicators

\begin{tabular}{|c|c|c|c|c|c|c|c|c|}
\hline \multirow[b]{2}{*}{ Country } & \multirow[b]{2}{*}{$\begin{array}{l}\text { Mean log } \\
\text { retirement } \\
\text { income }(\mathrm{PPP})\end{array}$} & \multicolumn{5}{|c|}{ Pension system } & \multicolumn{2}{|c|}{ Labour market } \\
\hline & & $\begin{array}{l}\text { Degree of } \\
\text { redistribution }\end{array}$ & $\begin{array}{l}\text { Minimum } \\
\text { contribution } \\
\text { years }\end{array}$ & $\begin{array}{l}\text { Care } \\
\text { entitlements }^{1}\end{array}$ & $\begin{array}{l}\text { Replacement } \\
\text { rate }\end{array}$ & $\begin{array}{l}\text { (Quasi-) mandatory } \\
\text { occupational } \\
\text { pensions }\end{array}$ & $\begin{array}{l}\text { Female } \\
\text { employment }^{2}\end{array}$ & $\begin{array}{l}\text { Maternal } \\
\text { employment }^{3}\end{array}$ \\
\hline Austria & 8.4 & 3 & 25 & 2.06 & 90.3 & $\mathrm{o}$ & $73 \cdot 4$ & $57 \cdot 4$ \\
\hline Belgium & $7 \cdot 4$ & 2 & $\mathrm{O}$ & 5 & $6_{5} \cdot 3$ & $\mathrm{O}$ & $6_{5} \cdot 0$ & 62.4 \\
\hline Czech Republic & 8.7 & 4 & 25 & 3 & 69.8 & o & 87.9 & 102.5 \\
\hline Denmark & 9.0 & 4 & $\mathrm{O}$ & $\mathrm{O}$ & 98.7 & 1 & $75 \cdot 3$ & 87.0 \\
\hline France & 8.4 & 3 & 0.25 & 5 & $6_{5} \cdot 3$ & $\mathrm{O}$ & 71.1 & 66.8 \\
\hline Germany (East) & 8.5 & 1 & 5 & 2.15 & 61.5 & o & 84.1 & 102.1 \\
\hline Germany (West) & $7 \cdot 7$ & 1 & 5 & 2.28 & 61.5 & o & 71.1 & 60.3 \\
\hline Italy & 7.1 & 1 & 20 & 3 & $5^{8.1}$ & o & $5^{0.5}$ & $5^{8.0}$ \\
\hline Poland & $7 \cdot 9$ & 3 & 21 & 1 & 55.2 & $\mathrm{o}$ & $77 \cdot 9$ & $87 \cdot 3$ \\
\hline Spain & $5 \cdot 5$ & 2 & 15 & 4 & 84.2 & $\mathrm{O}$ & $49 \cdot 7$ & $44 \cdot 3$ \\
\hline Sweden & $9 \cdot 2$ & 3 & 3 & 5 & 64.1 & 1 & 71.8 & 84.0 \\
\hline Switzerland & 8.4 & 3 & 1 & 0.57 & 70.2 & 1 & 62.0 & $44 \cdot 7$ \\
\hline The Netherlands & $7 \cdot 9$ & 4 & o & o & 105.5 & 1 & 53.0 & 48.2 \\
\hline
\end{tabular}

Notes: 1. The generation of the indicator for care entitlements is described in the Appendix and Table A.2. 2. Employment rate of women throughout the age span $25^{-} 59$ years as a percentage of the rate of men. 3 . Employment rate of mothers throughout the age span $25^{-} 59$ years as a percentage of the rate of non-mothers. PPP: purchasing power parity.

Sources: Leitner (2001); Organisation for Economic Co-operation and Development (2009, 2015); Queisser and Whitehouse (2006); US Social Security Administration (2014); own calculations from the Survey of Health, Ageing and Retirement in Europe Waves 1, 2 and SHARELIFE (Wave 3). 


\section{Katja Möhring}

\section{Method}

The main theoretical focus of this analysis lies on the interplay of individuallevel characteristics and country-level factors. These micro-macro linkages are estimated by means of regression models with cross-level interaction effects. In order to account for the nested structure of the data as well as the small number of macro-level units, country fixed-effects models are used instead of random-effects multi-level models (Bryan and Jenkins 2016; Hox 1998; Maas and Hox 2005). These regression models are appropriate for data-sets with a small number of macro-level units $(\mathrm{N}<20)$ since they control for the residual variance on the country level (Allison 2009). The equation for this kind of model is:

$$
y_{i j}=\underbrace{\gamma_{0}+\beta_{1} x_{1 i j}+\ldots+\beta_{k} x_{k i j}+\gamma_{l} z_{j} x_{1 i j}+\alpha_{1} u_{j 1}+\ldots+\alpha_{N-1} u_{j N-1}}_{\text {fixed part }}+\underbrace{e_{i j}}_{\text {random part }}
$$

where $y_{i j}$ is the individual-level outcome of observation $i$ in country $j ; \gamma_{\mathrm{o}}$ is the intercept over all countries; $\beta_{k} x_{k i j}$ is the estimator of individual-level variable number $k$ of observation $i$ in country $j ; \gamma_{l} z_{l j} x_{1 i j}$ is the estimator of crosslevel interaction of country-level variable $z_{j}$ and individual-level variable $x_{1 i j} ; \alpha_{1} u_{j 1}+\ldots+\alpha_{n-1} u_{j n-1}$ are the fixed effects for the $N-1$ countries; and $e_{i j}$ is the residual variance for observation $i$ within country $j$.

\section{Results}

In the following, I present the results on the retirement income of women focusing first on individual-level explanatory factors and then turning to country differences and the interplay of country-level factors with individual lifecourse characteristics. All models control for unobserved heterogeneity on the country level as described above.

\section{Individual determinants}

Table 3 shows the regression results of the country fixed-effects models for the retirement income of women age $6 \mathrm{o}-75$ years. Model 1 comprises the variable for the number of children and the socio-demographic control variables; employment and marital history factors are added in Models 2 and 3; Model 4 additionally includes interaction effects of the number of children with the employment history factors. Having children significantly reduces the retirement income of women: each child is associated with a 0.08 reduction in the logarithmised retirement income (Model 1). Women who were 
T А В L E 3. Country fixed-effects regression models for women aged 6o-75 years with logarithmised individual annual net retirement income (purchasing power parity-adjusted) as dependent variable

\begin{tabular}{|c|c|c|c|c|c|c|c|c|}
\hline \multirow[b]{2}{*}{ Number of children } & \multicolumn{2}{|c|}{ Model 1} & \multicolumn{2}{|c|}{ Model 2} & \multicolumn{2}{|c|}{ Model $_{3}$} & \multicolumn{2}{|c|}{ Model 4} \\
\hline & $-0.083^{* *}$ & $(0.026)$ & 0.015 & $(0.026)$ & 0.013 & $(0.026)$ & 0.049 & $(0.055)$ \\
\hline Born before $194^{\circ}$ & $0.470^{* * * *}$ & $(0.065)$ & $0.54^{6 * * *}$ & $(0.062)$ & $0.531^{* * *}$ & $(0.064)$ & $0.5^{2} 3^{* * *}$ & $(0.064)$ \\
\hline \multicolumn{9}{|l|}{ Educational level (Ref.: Low): } \\
\hline Medium & $0.459^{* * *}$ & $(0.076)$ & 0.106 & $(0.078)$ & 0.107 & $(0.078)$ & 0.098 & $(0.078)$ \\
\hline High & $0.871^{* * * *}$ & $(0.102)$ & 0.123 & $(0.112)$ & 0.122 & $(0.112)$ & 0.125 & $(0.113)$ \\
\hline \multicolumn{9}{|l|}{ Family status (Ref.: Married): } \\
\hline Remarried & $0.768 * * *$ & $(0.155)$ & $0.449^{* *}$ & $(0.148)$ & $0.533^{* *}$ & $(0.178)$ & $0.55^{8 * *}$ & $(0.179)$ \\
\hline Divorced & $1.480 * * *$ & (o.ogo) & $1.218^{* * *}$ & $(0.090)$ & $1.284^{* * *}$ & $(0.110)$ & $1.287^{* * *}$ & $(0.110)$ \\
\hline Widowed & $1.717^{* * *}$ & $(0.065)$ & $1.687^{* * *}$ & $(0.066)$ & $1.724^{* * *}$ & $(0.076)$ & $1.725^{* * *}$ & $(0.076)$ \\
\hline Never married & $1.818 * * *$ & $(0.116)$ & $1.49^{8 * * *}$ & $(0.114)$ & $1.621 * * *$ & $(0.167)$ & $1.573^{* * *}$ & $(0.170)$ \\
\hline \multicolumn{9}{|l|}{ Lifecourse indicators: } \\
\hline Years employed & & & $0.050^{* * *}$ & $(0.003)$ & $0.05 \mathrm{O}^{* * * *}$ & $(0.003)$ & $0.061^{* * *}$ & $(0.005)$ \\
\hline Share of part-time employment & & & -0.001 & $(0.001)$ & -0.001 & $(0.001)$ & -0.002 & $(0.002)$ \\
\hline Occupational status (ISEI, mean over career) & & & $0.018^{* * *}$ & $(0.003)$ & $0.018 * * *$ & (o.003) & $0.014^{* * *}$ & $(0.004)$ \\
\hline Years married & & & & & 0.003 & $(0.003)$ & 0.003 & $(0.003)$ \\
\hline \multicolumn{9}{|l|}{ Interaction effects with number of children: } \\
\hline$\times$ Years in employment & & & & & & & $-0.005^{* *}$ & $(0.002)$ \\
\hline$\times$ Share of part-time & & & & & & & 0.000 & $(0.001)$ \\
\hline$\times$ Occupational status & & & & & & & 0.002 & $(0.001)$ \\
\hline$\times$ Years married & & & & & & & -0.001 & $(0.001)$ \\
\hline & & & & + Countr & dummies & & & \\
\hline Constant & $6.878 * * *$ & $(0.166)$ & $5 \cdot 44^{6 * * *}$ & $(0.178)$ & $5 \cdot 333^{* * *}$ & $(0.210)$ & $5 \cdot 23^{6 * * *}$ & $(0.244)$ \\
\hline $\mathrm{N}$ & $5^{2} 3^{1}$ & & $5^{2} 3^{1}$ & & $5^{2} 3^{1}$ & & $5^{231}$ & \\
\hline$R^{2}$ & 0.243 & & $0.3^{15}$ & & 0.315 & & 0.316 & \\
\hline Adjusted $R^{2}$ & 0.240 & & 0.312 & & 0.311 & & 0.312 & \\
\hline
\end{tabular}

Notes: Standard errors are given in parentheses. Ref.: reference category. ISEI: International Socio-Economic Index of Occupational Status.

Source. Own calculations from the Survey of Health, Ageing and Retirement in Europe Waves 1, 2 and SHARELIFE (Wave 3).

Significance levels: $* * p<0.01, * * * p<0.001$ 
married at the point of the interview receive a significantly lower retirement income than remarried, divorced, widowed and never-married women. The highest income difference exists between never-married and married women, but even remarried women achieve a significantly higher retirement income than those who were continuously married. The educational level has a positive effect: medium and higher-educated women receive a significantly higher income than lower-educated women (Model 1). In Model 2 variables on the individual employment history are added. First of all, the explanatory power increases considerably from an adjusted $R^{2}$ of 24.0 to 31.2 per cent, reflecting the high impact of factors related to women's employment history. The retirement income of women in general is increased by 0.05 units of the logarithmised income for each year in employment. A further increase is related to women's occupational status: the higher the mean occupational status over the career, the higher the subsequent retirement income. The proportion of part-time employment has a negative albeit not significant effect on women's retirement income. After including variables on the individual employment history in Model 2, the negative effect of the number of children becomes insignificant. Consequently, mothers' lower retirement income is mainly a result of their fewer years in employment and lower-status jobs throughout their career. In Model 3, information on marital history is added. The duration of marriage does not have a significant impact on the retirement income in addition to the current marital status. To sum up, the individual-level results support Hypotheses 1 and 2: the retirement income of women is significantly reduced with each child, however, considering factors related to employment diminishes the retirement income penalty to motherhood. One additional result is noteworthy. After the inclusion of variables related to employment history, the effect of educational status becomes not significant. Consequently, for women their actual labour market participation has a higher relevance to their retirement income than their initial educational degree.

The estimations in Model 4 focus on the interaction of the number of children with lifecourse factors relating to employment history. The negative interaction effect of the number of children and years in employment shows that the positive career effect is significantly reduced for mothers. Supporting the assumption formulated in Hypothesis 3, mothers' retirement income increases to a lesser extent with each additional year of employment compared to non-mothers, however, this reduction is rather small (Model 4). For the two other employment history factors as well as the number of years being married, the interaction effects are not significant, indicating that the main effects are valid for all women irrespective of their parenting history. 

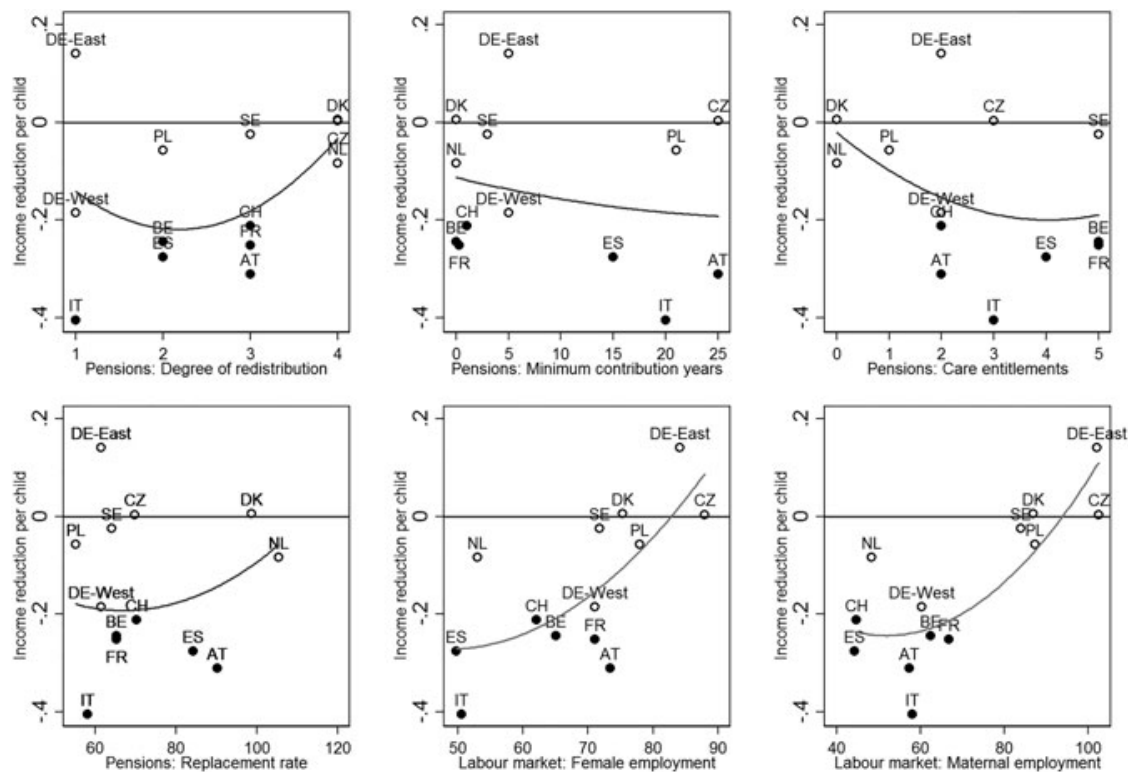

Figure 2. Estimated reduction in log retirement income per child in each country in relation to macro-indicators.

Notes: Calculation with country-separated regression models for the individual retirement income $(\log )$ of women. The binary indicator for the relevance of mandatory occupational pensions is not depicted. AT: Austria. BE: Belgium. CH: Switzerland. CZ: Czech Republic. DE-East: Germany (East). DE-West: Germany (West). DK: Denmark. ES: Spain. FR: France. IT: Italy. NL: The Netherlands. PL: Poland. SE: Sweden.

Source: Own calculations from the Survey of Health, Ageing and Retirement in Europe Waves 1, 2 and SHARELIFE (Wave 3).

\section{Country differences}

While the aim of the regressions so far was to describe individual-level determinants of women's retirement income controlling for country-level heterogeneity, the following estimations shed more light on country differences. In a first step, country-separated regression models are estimated to calculate the motherhood penalty in the retirement income for each country. Figure 2 comprises scatter plots showing the size and the significance of the estimated reduction in the logarithmised retirement income per child in each country in relation to macro-indicators. The plots depict the coefficient of the variable number of children from country-separated regression models. Hollow scatter points indicate that the coefficient is not significant in that respective country. Generally, the income penalty for motherhood is not significant and small, or even reversed in the Scandinavian as well as the former Socialist countries including Germany (East). The income gap is 
also not significant in Germany (West) and the Netherlands. By far the largest estimated reduction in the retirement income per child exists in Italy; in addition, both Austria and Belgium show large gaps.

Regarding the values of the macro-indicators, the following picture emerges. First of all, a clear link exists between the estimated motherhood penalty in the retirement income and the degree of redistribution in the pension system. More redistributive systems are accompanied by lowerincome differences, with the exception of Germany (East). The relationship to the minimum required number of contribution years is less straightforward. While in some countries with low requirements, large income gaps exist (e.g. Belgium and Switzerland), other countries feature small gaps despite their high eligibility requirements (e.g. Poland and Czech Republic). The relation of the motherhood penalty in retirement income and the generosity of pension care entitlements is not consistent either. Among the countries with rather generous entitlements, small (e.g. Sweden) as well as large income penalties for motherhood can be found (e.g. Belgium). Countries with less generous or even no entitlements also feature low income differences (e.g. Denmark and the Netherlands). No clear pattern can be found for the pension replacement rate: small retirement income gaps between mothers and non-mothers exist in countries with high replacement rates (e.g. Denmark and the Netherlands) as well as in countries with low replacement rates (e.g. Poland). The relationship between the two labour market-related macro-indicators and the motherhood penalty is less ambiguous: for both indicators the relationship is negative with larger income gaps in countries with higher gender inequality or a higher differential between mothers and non-mothers in employment. However, the Netherlands represent an exception. Here, the difference in the employment participation between men and women is high, while a retirement income penalty for motherhood does not exist.

Besides the link of the motherhood penalty in the retirement income and the different country-level characteristics, the relationship of female employment and the set-up of the national pension system are also of relevance for women's retirement income. High female and maternal employment rates exist especially in the Scandinavian and former Socialist countries, whereas low rates can be found in the Southern European countries as well as in the Netherlands ( see Table 2). Within both groups of countries, however, a variety of different types of pension systems are in place. Among countries with low female employment rates, systems with a low (e.g. Italy) as well as a high level of redistribution (e.g. the Netherlands) can be found; the same applies to the countries with high female and maternal employment rates. Consequently, no clear pattern emerges with regard to the link between pension systems and female employment. 
T A B L E 4. Coefficients from linear country fixed-effects regression models on log income for women aged 6o-75 years, cross-level interaction effects (based on Model 3, Table 2)

\begin{tabular}{|c|c|c|c|c|}
\hline & \multicolumn{2}{|c|}{$\begin{array}{l}\text { Main effect: } \\
\text { number of children }\end{array}$} & \multicolumn{2}{|c|}{$\begin{array}{l}\text { Cross-level } \\
\text { interaction effect }\end{array}$} \\
\hline \multicolumn{5}{|l|}{ Pension system: } \\
\hline Degree of redistribution & $-0.167^{*}$ & $(0.071)$ & $0.071^{* *}$ & $(0.023)$ \\
\hline Minimum contribution years & 0.049 & $(0.033)$ & -0.004 & $(0.002)$ \\
\hline Pension care entitlements & $0.101 *$ & $(0.040)$ & $-0.030^{*}$ & $(0.012)$ \\
\hline Replacement rate & -0.123 & $(0.108)$ & 0.002 & $(0.001)$ \\
\hline (Quasi-)mandatory occupational pensions & -0.021 & $(0.366)$ & $0.145^{* *}$ & $(0.003)$ \\
\hline \multicolumn{5}{|l|}{ Labour market: } \\
\hline Female employment & $-0.285^{*}$ & $(0.142)$ & $0.005^{*}$ & $(0.002)$ \\
\hline Maternal employment & -0.144 & $(0.092)$ & $0.002 *$ & $(0.001)$ \\
\hline
\end{tabular}

Notes: Cluster-robust standard errors are given in parentheses. Control variables are as in Model 3 (Table 3 ).

Source. Own calculations from the Survey of Health, Ageing and Retirement in Europe Waves 1, 2 and SHARELIFE (Wave 3 ).

Significance levels: $* p<0.0_{5}, * * p<0.01$.

\section{Institutional determinants}

In order to examine further the relevance of institutional and structural factors for mothers' retirement income, cross-level interaction effects of the individual-level variable number of children with the different country indicators are integrated in the regression models step by step (basis is Model 3 in Table 3); the results are shown in Table 4. The interaction effects with the degree of redistribution in the pension system, with pension care entitlements, and with women's and mothers' employment rates are significant. Therefore, the relationship of retirement income and motherhood, as measured with the variable number of children, is not universal within the country sample, but dependent on a country's intuitional and structural characteristics with respect to the pension system design and the labour market conditions for women and mothers. In the remainder of the section, I will describe the results of the significant cross-level interaction effects in detail.

The interaction effect of number of children and the degree of redistribution in the pension system is positive, showing that redistributive pension schemes partially compensate for the negative impact of motherhood on retirement income. The interaction effect of the number of children and the generosity of pension care entitlements is negative: the more generous these entitlements are in a country, the stronger the negative relationship between motherhood and retirement income. In countries 


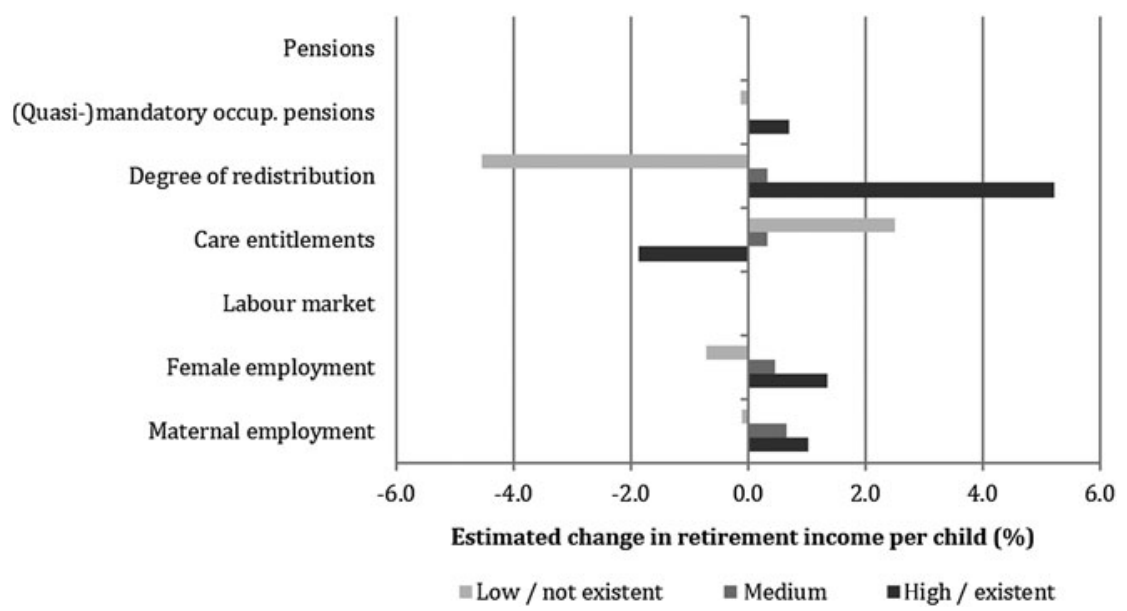

Figure 3. Estimated reduction in log retirement income per child for different values of the macro-indicators.

Notes: Calculation of the predicted incomes based on the regression models in Table 3. occup.: occupational.

Source. Own calculations from the Survey of Health, Ageing and Retirement in Europe Waves 1, 2 and SHARELIFE (Wave 3).

with mandatory or quasi-mandatory occupational pension schemes, the gap in pension income between mothers and non-mothers is significantly lower than in countries without such schemes. Both indicators reflecting gender inequalities in the labour market show the expected impact: the positive interaction effects indicate that the higher the female and the maternal employment participation, respectively, the less intense the negative effect of motherhood on retirement income. The indicators for the minimum contribution years and for the pension replacement rate are not significant.

Figure 3 includes a graphical depiction of the cross-level interaction effects. For different values of the macro-indicators with significant interaction effects, the estimated percentage change in the logarithmised retirement income per child is shown, holding all other variables in the regression models at the sample mean. The largest differences are related to the degree of redistribution in the pension system. Whereas in countries with a highly redistributive pension system, a motherhood premium in retirement income exists rather than a penalty, in countries with a low degree of redistribution, mothers' incomes are reduced by 4.5 per cent per child. For the other macro-indicators, the effects are less pronounced. Mothers' retirement incomes are reduced by 1.9 per cent per child in countries with favourable care entitlements, whereas the reverse applies to countries where these entitlements are less beneficial or even non-existent. The 
income increase associated with the existence of mandatory or quasi-mandatory occupational pension schemes amounts to only 0.8 percentage points per child. The two labour market indicators both show the same pattern: in countries with low gender inequality in employment rates, mothers even achieve a slightly higher retirement income than nonmothers. The same applies to countries with a higher maternal employment rate; however, the differences for both indicators are very small.

To sum up, the results on the relationship of pension system characteristics and women's retirement income are mixed. Most crucial for balancing mothers' interrupted careers is the general degree of redistribution in the pension system. The reverse applies to pension care entitlements: these are not associated with a compensation, but rather go along with an intensification of the motherhood penalty in the retirement income. Countries with mandatory or quasi-mandatory occupational schemes exhibit a lower gap between mothers' and non-mothers' retirement income, however, the difference is small. Therefore, Hypothesis $4^{\mathrm{a}}$ is refuted regarding pension care entitlements, but clearly supported regarding the compensating effect of redistributive pension system elements. Furthermore, Hypothesis $4 \mathrm{~b}$ on the high relevance of redistributive pension schemes is clearly supported. The general generosity of pension benefits as measured by the replacement rate is not significantly related to mothers' retirement income. A reason for this might be that replacement rates refer to an artificial 'median earner' that does not reflect non-standard employment careers which are typical for mothers (Möhring 2015).

\section{Conclusion}

The analysis of the individual and institutional determinants of mothers' old age income position has led to two central results. First, mothers benefit in terms of their retirement income from continued or re-started labour market activity; however, being employed pays off less for mothers than for childless women. This means that incomplete or interrupted careers, part-time work and lower-status jobs are not the only reason for mothers' lower retirement income. Additional disadvantages may emerge from wage discrimination and a lower likelihood of being promoted. Against the background of demographic ageing this does not only apply to child care, but also to the increasing number of women interrupting their employment in order to provide informal care for older or frail relatives. Second, the analysis of institutional factors has shown that generous pension care entitlements are rather associated with more pronounced income differences between mothers and non-mothers, than they are able 
to provide a compensation for parental leave periods. The only way in which differences in employment participation over the lifecourse can be balanced is a generally redistributive design of the pension system; this means, the provision of sufficient benefits that are not dependent on one's employment history. This reflects that extensive care entitlements are not required if universal access to sufficient pension benefits is granted then there is no need to compensate for mothers' career interruptions.

Concerning individual determinants, a second interesting finding relates to the relative importance of educational status and employment history: the empirical results show that the impact of the working history exceeds that of the initial educational degree, contrary to previous results for men (Möhring 2015). Accordingly, for women the interdependencies between different lifecourse phases are more complex, more differentiated, and thus more difficult to describe in terms of typical patterns and their outcome than for men. Hence, the theoretical assumption of a highly interdependent normal lifecourse is less suitable to understand women's lifecourses. This also becomes evident in the fact that the replacement rate as indicator for pension generosity, which refers to the pension income of a 'medium earner' with a standard career, does not play a role for women's retirement income.

The analysis of institutional factors has shown that generous pension care entitlements do not sufficiently compensate for cutbacks in the employment career due to care obligations. These entitlements rather appear as a 'fig leaf' in countries where pension systems as a whole are strongly earnings-related. Sweden is the only country which features both a universal basic pension scheme and well-developed pension care entitlements. The general degree of redistribution in the pension system and the gender inequality in working histories are, by contrast, of high relevance for the later-life income of mothers. The motherhood penalty in retirement income is significantly lower if universal pension benefits, which guarantee an income independent of the individual's working history, exist in a country. The same applies to countries with low gender inequality and high support for maternal employment in working life. This clearly expresses that a positive climate in favour of female employment in general is also accompanied by lower inequality between mothers and childless women.

For the combined effect of women's lifecourse configurations and gender inequality in a country, the results reveal a remarkable relationship. It appears that women in more traditional countries who follow the predominant norm of full-time housewife and mother are most penalised in terms of their retirement income, whereas women in these countries who do not follow this norm benefit in terms of their retirement income. By contrast, in countries which are more oriented towards the dual-earner model, equality in retirement income of women with different lifecourse configurations is 
much higher. Women here are not 'penalised' for the different life choices they make and these less traditional countries actually provide better institutional compensation for family-centred lifecourses.

The interplay of the different macro-indicators can be further exemplified contrasting the situations in the Netherlands and Italy. Both countries had a high gender inequality in employment throughout the 2oth century, however, very differently designed pension systems. In the Netherlands, gender inequality in employment histories is high due to the high prevalence of part-time employment among women (Visser 2002). Pension care entitlements do not exist, however, the pension system is strongly redistributive featuring a generous residence-based basic pension. As a consequence, motherhood is not related to a lower personal retirement income. In Italy, in contrast, the income reduction associated with motherhood is the highest in the sample despite generous pension care entitlements. Here, the degree of redistribution in the pension system is low. Therefore, it can be concluded that slight increases in pension care entitlements, as legislated in Germany in 2014, are not appropriate to compensate adequately for the reduction in pension income due to child care (Bach et al. 2014). On the contrary, the general conditions favouring the reconciliation of work and family life need to be improved. Furthermore, adequate universal basic or targeted pension schemes are indispensable to avoid the general discrimination of care provision in earnings-related pension systems.

The results have to be interpreted against the background of the limitations of the study. First of all, the measure for occupational status provided in the SHARELIFE life history data is not very detailed and information on earnings throughout the career is not available. Therefore, some factors possibly causing the income penalty to motherhood cannot be controlled for. Due to the long time period covered by the life history data, accurate measures for family policy are not available. This drawback is compensated through the use of macro-indicators generated from SHARELIFE information; however, these only represent approximations. Most importantly, despite this examination of women's retirement income covering more countries than have been included in previous research, the number of countries is still too low to apply standard multi-level regression techniques.

\section{Acknowledgements}

I am grateful to Simone Scherger, Bernhard Ebbinghaus, the Deputy Editor of Ageing \& Society Athina Vlachantoni, and three anonymous reviewers for their 


\section{Katja Möhring}

helpful comments on earlier versions of this paper. Furthermore, I would like to thank Lisa Elfering and Sarah Jensen for their support as well as Elvira Gonzalez, Joanna Ratajczak-Tuchołka, Klaus Petersen, Ole Beier Sørensen and Matthieu Leimgruber for their explanatory notes on the respective pension regulations in their countries. All remaining errors are mine. No ethical approval was required.

\section{NOTES}

1 This paper uses data from SHARE Waves 1, 2 and 3 (SHARELIFE) (DOIs: 10.6103 /SHARE.w1.5oo, 10.6103/SHARE.w2.500, 10.6103/SHARE.w3.5 Oo); see Börsch-Supan, Brandt and Schröder (2013) for methodological details. The SHARE data collection have been primarily funded by the European Commission through FP5 (QLK6-CT-2001-oo36o), FP6 (SHARE-I 3 : RII-CT2006-o62 193, COMPARE: CIT5-CT-2005-028857, SHARELIFE: CIT4-CT-2006o28812) and $\mathrm{FP}_{7}$ (SHARE-PREP: No. 211909 , SHARE-LEAP: No. 227822, SHARE M4: No. 261982). Additional funding from the German Ministry of Education and Research, the US National Institute on Aging (Uo1_AGo9740${ }_{13} S_{2}$, Po1_AGoo5842, Po1_AGo8291, P3O_AG12815, R2 1_AGo25169, Y1-AG4553-01, IAG_BSRo6-1 1, OGHA_04-064) and from various national funding sources is gratefully acknowledged (see www.share-project.org).

2 The mandatory personal scheme 'Open Pension Funds' in Poland was introduced in 1999 and applies to birth cohorts after 1968 (OECD 2009). Thus, it is not relevant to the retirees in the SHARELIFE sample.

\section{Appendix}

\section{Generation of the pension care entitlements indicator}

To measure the generosity of pension care entitlements (PCE), a new indicator is developed. The regulations of each single country in the data sample were evaluated with respect to the four dimensions universality, calculation method, level and optional upgrading of part-time employment ( see Table A2). The first dimension of universality reflects whether the entitlements are granted generally for mothers irrespective of their employment behaviour, or whether they are conditional upon an employment interruption. While in most countries PCE are a general reward for parenthood, in some countries they are only credited if the mother was indeed not employed (Samek Lodovici, Crepaldi and Corsi 2011). Flexible calculation methods exist in France and Sweden, where the most beneficial option is chosen from a range of possibilities. The dimension 'level of benefits' refers to the duration of the career break that is accounted for (for countries with earnings-related benefits), or respectively the actual level of credits in mean contribution years (for countries with flat-rate benefits). Lastly, in some countries PCE include an upgrading of part-time 
Motherhood and retirement income in Europe 2585

T A в L E A 1 . Sample statistics of the individual-level variables (unweighted)

\begin{tabular}{lrrrr}
\hline Variable & Mean & SD & Minimum & Maximum \\
\hline Individual annual retirement income (log) & 7.86 & 2.84 & 2.40 & 12.81 \\
Number of children & 2.30 & 1.34 & 0 & 6 \\
Born before 1940 & 0.48 & 0.50 & 0 & 1 \\
Medium educational level & 0.29 & 0.45 & 0 & 1 \\
High educational level & 0.13 & 0.34 & $\mathrm{O}$ & 1 \\
Family status: remarried & 0.04 & 0.19 & $\mathrm{O}$ & 1 \\
Family status: divorced & 0.07 & 0.26 & $\mathrm{O}$ & 1 \\
Family status: widowed & 0.19 & 0.39 & $\mathrm{O}$ & 1 \\
Family status: never married & 0.04 & 0.20 & $\mathrm{O}$ & 1 \\
Years employed & 19.14 & 13.77 & $\mathrm{O}$ & 35 \\
Share of part-time employment & 15.76 & 32.77 & $\mathrm{O}$ & 100 \\
Occupational status (mean ISEI over career) & 32.97 & 18.02 & $\mathrm{O}$ & 70 \\
Years married & 20.70 & 8.35 & 0 & 35 \\
\hline
\end{tabular}

Notes: SD: standard deviation. ISEI: International Socio-Economic Index of Occupational Status. Source: Own calculations from the Survey of Health, Ageing and Retirement in Europe Waves 1, 2 and SHARELIFE (Wave 3 ).

T А в L E A 2. The design of pension entitlements for parenthood and child care in Europe

\begin{tabular}{|c|c|c|}
\hline Dimension and description & Value & Countries \\
\hline \multicolumn{3}{|l|}{ Universality: } \\
\hline Unconditional entitlements & 1 & $\begin{array}{l}\text { Austria, Switzerland, Germany, Belgium, } \\
\text { France, Sweden, Poland }\end{array}$ \\
\hline Only for employment interruption & $\mathrm{o}$ & Czech Republic, Spain, Italy \\
\hline \multicolumn{3}{|l|}{ Calculation method: } \\
\hline Flat-rate & o & Austria, Switzerland, Germany, Poland \\
\hline Earnings-related & 1 & Belgium, Czech Republic, Spain, Italy \\
\hline Flexible or combination & 2 & Sweden, France \\
\hline \multicolumn{3}{|l|}{ Level $^{1}$ : } \\
\hline None or less than one year & o & Switzerland (before 1997) \\
\hline One to three year(s) & 1 & $\begin{array}{l}\text { Austria (for women born before 1955), } \\
\text { Belgium, Germany, Italy, Poland, Spain, } \\
\text { France }\end{array}$ \\
\hline More than three years & 2 & $\begin{array}{l}\text { Austria (for women born as of 1955), Sweden, } \\
\text { Czech Republic, Switzerland (as of 1997) }\end{array}$ \\
\hline \multicolumn{3}{|l|}{ Upgrading of part-time employment: } \\
\hline Existing & 2 & $\begin{array}{l}\text { Belgium, Germany (for children born as of } \\
\text { 1992), Spain }\end{array}$ \\
\hline Only for low-income parents & 1 & France, Italy \\
\hline Not existing & o & $\begin{array}{l}\text { Austria, Switzerland, Czech Republic, } \\
\text { Germany (for children born before 1992), } \\
\text { Poland, Sweden }\end{array}$ \\
\hline
\end{tabular}

Notes: Denmark and the Netherlands are assigned the value of o. 1. For countries with earningsrelated benefits 'Level' corresponds to the duration of the career break that is accounted for; for countries with flat-rate benefits it refers to the actual level of credits in mean contribution years. Sources: Own compilation on the basis of Eidgenössische Kommission für Frauenfragen (20og); Frericks, Maier and de Graaf (2007); Horstmann and Hüllsman (2009); Organisation for Economic Co-operation and Development (2015); Samek Lodovici, Crepaldi and Corsi (2011). 


\section{$25^{86}$ Katja Möhring}

employment in the pension calculation. In Germany, for example, mothers who work part-time to care for children under 10 receive an upgrading of these pension entitlements up to the mean wage (Horstmann and Hüllsman 2009). These different dimensions of PCE are summarised to one unique index by means of adding the assigned values (see Table A2). Variation over time due to policy reforms in some countries was taken into account as far as they apply to the birth cohorts of women included in the analysis sample. The most significant reform took place in Switzerland. Whereas the country's pension system did not incorporate specific care credits until 1997 , the newly implemented regulations are by far the most generous in the country sample.

\section{References}

Abendroth, A.-K., Huffman, M. L. and Treas, J. 2014. The parity penalty in life course perspective: motherhood and occupational status in 13 European countries. American Sociological Review, 79, 5, 993-1014.

Allison, P. D. 2009. Fixed Effects Regression Models. Sage, Thousand Oaks, California.

Bach, S., Buslei, H., Coppola, M., Haan, P. and Rausch, J. 2014. Die Verteilungswirkungen der Mütterrente. DIW Wochenbericht, 81, 20, 447-56.

Bettio, F., Tinios, P. and Betti, G. (eds) 2013. The Gender Gap in Pensions in the EU. European Commission - Directorate-General for Justice, Luxembourg.

Boeckmann, I., Misra, J. and Budig, M.J. 2015. Cultural and institutional factors shaping mothers' employment and working hours in postindustrial countries. Social Forces, 93, 4, $1301-33$.

Börsch-Supan, A., Brandt, M. and Schröder, M. 2013. SHARELIFE: one century of life histories in Europe. Advances in Life Course Research, 18, 1, 1-4.

Bryan, M. L. and Jenkins, S. P. 2016. Multilevel modelling of country effects: a cautionary tale. European Sociological Review, 32, 1, 3-22.

Budig, M.J. and England, P. 2001. The wage penalty for motherhood. American Sociological Review, 66, 2, 204-25.

Budig, M.J., Misra, J. and Boeckmann, I. 2012. The motherhood penalty in crossnational perspective: the importance of work-family policies and cultural attitudes. Social Politics: International Studies in Gender, State Ev Society, 1 9, 2, 163-93.

Burkevica, I., Humbert, A. L., Oetke, N. and Paats, M. 2015. Gender Gap in Pensions in the EU. Research Note to the Latvian Presidency. The European Institute for Gender Equality (EIGE), Luxembourg. Available online at http://bookshop.europa.eu/ uri?target=EUB:NOTICE:MHo415087:EN:HTML [Accessed 27 June 2016].

Christelis, D. 201 1. Imputation of Missing Data in Waves $I$ and 2 of SHARE. Available online at http://share-dev.mpisoc.mpg.de/fileadmin/pdf_documentation/ Imputation_of_Missing_Data_in_Waves_1_and_2_of_SHARE.pdf [Accessed 21 March 2014].

Crystal, S. and Shea, D. 1990. Cumulative advantage, cumulative disadvantage, and inequality among elderly people. The Gerontologist, 3o, 4, 437-43.

Crystal, S., Shea, D. G. and Reyes, A. M. 2016. Cumulative advantage, cumulative disadvantage, and evolving patterns of late-life inequality. The Gerontologist. Published online 3o March 2016. doi:10.1093/geront/gnwo56. 
Dewilde, C. 2003. A life-course perspective on social exclusion and poverty. British Journal of Sociology, 54, 1, 109-28.

Dewilde, C. 201 2. Lifecourse determinants and incomes in retirement: Belgium and the United Kingdom compared. Ageing E Society, 32, 4, 587-615.

Dotti Sani, G. M. 2015. Within-couple inequality in earnings and the relative motherhood penalty. A cross-national study of European countries. European Sociological Review, 31, 6, 667-82.

Ebbinghaus, B. and Neugschwender, J. 2011. The public-private pension mix and old age income inequality in Europe. In Ebbinghaus, B. (ed.), The Varieties of Pension Governance: Pension Privatization in Europe. Oxford University Press, Oxford, 384-422.

Eidgenössische Kommission für Frauenfragen 2009. Frauen Macht Geschichte. Zur Geschichte der Gleichstellung in der Schweiz I 848-20oo, Die Stellung der Frau in der AHV und der beruflichen Vorsorge. Available online at http://www.ekf.admin.ch/ dokumentation/o0444/00517/index.html?lang=de\#sprungmarkeo_o [Accessed 26 May 2014].

Elder, G. H., Kirkpatrick Johnson, M. and Crosnoe, R. 2003. The emergence and development of life course theory. In Mortimer, J. T. and Shanahan, M.J. (eds), Handbook of the Life Course. Kluwer, New York, 3-19.

Evandrou, M. and Glaser, K. 2003. Combining work and family life: the pension penalty of caring. Ageing E Society, 23, 5, 583-601.

Fasang, A. E., Aisenbrey, S. and Schömann, K. 2013. Women's retirement income in Germany and Britain. European Sociological Review, 29, 5, 968-80.

Frericks, P., Maier, R. and de Graaf, W. 2007. Male norms and female adjustments: the influence of care credits on gender pension gaps in France and Germany. European Societies, 10, 1, 97-119.

Frommert, D., Heien, T. and Loose, B. L. 2013. Auswirkungen von Kindererziehung auf Erwerbsbiografien und Alterseinkommen von Frauen. WSI-Mitteilungen, 2013, $5,33^{8-49}$.

Ganzeboom, H. B. G. and Treiman, D. J. 1996. Internationally comparable measures of occupational status for the 1988 International Standard Classification of Occupations. Social Science Research, 25, 3, 201-39.

Gash, V. 2009. Sacrificing their careers for their families? An analysis of the penalty to motherhood in Europe. Social Indicators Research, 93, 3, 569-86.

Ginn, J., Daly, M. and Street, D. 2001. Engendering pensions: a comparative framework. In Ginn, J., Street, D. and Arber, S. (eds), Women, Work, and Pensions: International Issues and Prospects. Open University Press, Buckingham, UK, 1-10.

Haan, P. and Thiemann, A. 2015. Ausweitung der in der Rentenversicherung anrechenbaren Kindererziehungszeiten: Mütter pausieren nicht länger vom Job. DIW Wochenbericht, 82, 47, $1119^{-25}$.

Horstmann, S. and Hüllsman, J. 2009. The Socio-economic Impact of Pension Systems on Women. Report prepared for European Commission, Directorate-General for Employment, Social Affairs, and Equal Opportunities, Brussels. Available online at http://ec.europa.eu/social/BlobServlet?docId=5001\&langId=en [Accessed 15 March 2014].

Hox, J.J. 1998. Multilevel modeling: when and why. In Balderjahn, I., Mathar, R. and Schader, M. (eds), Classification, Data Analysis, and Data Highways. Springer, New York, 147-54.

Immergut, E. M. and Anderson, K. M. 2009. Editors' introduction: the dynamics of pension politics. In Immergut, E. M., Anderson, K. M. and Schulze, I. (eds), The Handbook of West European Pension Politics. Oxford University Press, Oxford, 1-45. 


\section{$25^{88}$ Katja Möhring}

Leisering, L. 2003. Government and the life course. In Mortimer, J. T. and Shanahan, M.J. (eds), Handbook of the Life Course. Springer, New York, $205^{-25}$.

Leitner, S. 2001. Sex and gender discrimination within EU pension systems. Journal of European Social Policy, 11, 2, 99-115.

Lewis, J. 1992. Gender and the development of welfare regimes. Journal of European Social Policy, 2, 3, 159-73.

Lewis, J. 2010. Work-Family Balance, Gender and Policy. Edward Elgar, Cheltenham, UK.

Maas, C. J. M. and Hox, J.J. 2005. Sufficient sample sizes for multilevel modeling. Methodology: European Journal of Research Methods for the Behavioral and Social Sciences, 1, 3, 86-92.

Möhring, K. 2015. Employment histories and pension incomes in Europe. European Societies, 17, 1, 3-26.

Möhring, K. 2016. Life course regimes in Europe: individual employment histories in comparative and historical perspective. Journal of European Social Policy, 26, 2, $124-39$.

Organisation for Economic Co-operation and Development (OECD) 2009. Pensions at a Glance 2009. OECD Publishing. Available online at http://www.oecd-ilibrary. org/finance-and-investment/pensions-at-a-glance-2009_pension_glance-20o9-en [Accessed 3 January 2017].

Organisation for Economic Co-operation and Development (OECD) 2015. Pensions at a Glance 20 I 5. OECD Publishing. Available online at http://www.oecd-ilibrary. org/social-issues-migration-health/pensions-at-a-glance-2015_pension_glance-2015en [Accessed 25 November 2015].

Queisser, M. and Whitehouse, E. R. 2006. Neutral or Fair? Actuarial Concepts and Pension-System Design. OECD Publishing. Available online at https://ideas.repec.

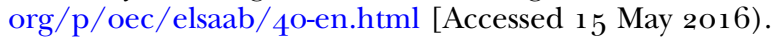

Samek Lodovici, M., Crepaldi, C. and Corsi, M. 2011. The Socio-economic Impact of Pension Systems on the Respective Situations of Women and Men and the Effects of Recent Trends in Pension Reforms. Synthesis report financed by and prepared for the use of the European Commission. Available online at http://ec.europa.eu/justice/ gender-equality/files/equal_economic_independence/pensions_report_en.pdf [Accessed 14 March 2014].

Schröder, M. 2011. Retrospective Data Collection in the Survey of Health, Ageing and Retirement in Europe. SHARELIFE Methodology. Available online at http://www. share-project.org/t3/share/fileadmin/pdf_sharelife/Publications/FRB-Methodolo gy_feb2011_color-1.pdf [Accessed 23 June 2011].

Sefton, T., Evandrou, M. and Falkingham, J. 2011 . Family ties: women's work and family histories and their association with incomes in later life in the UK. Journal of Social Policy, 4o, 1, 41-69.

Sefton, T., Evandrou, M., Falkingham, J. and Vlachantoni, A. 2011 . The relationship between women's work histories and incomes in later life in the UK, US and West Germany. Journal of European Social Policy, 2 1, 1, 20-36.

Stata Corp. 2011. Stata Multiple-imputation Reference Manual. Stata Press, College Station, Texas.

Tinios, P., Bettio, F. and Betti, G. 2015. Men, Women and Pensions. Report prepared for the European Commission, Luxembourg. Available online at http://book shop.europa.eu/uri?target=EUB:NOTICE:DSo2 15321 :EN:HTML [Accessed 27 June 2016].

US Social Security Administration, Office of Retirement and Disability Policy 2014. Social Security Programs Throughout the World: Europe, 2014. Available online at 
Motherhood and retirement income in Europe $25^{89}$

https://www.ssa.gov/policy/docs/progdesc/ssptw/2014-2015/europe/index.html [Accessed 28 July 2016].

Visser, J. 2002. The first part-time economy in the world: a model to be followed? Journal of European Social Policy, 1 2, 1, 23-42.

Waldfogel, J. 1997. The effect of children on women's wages. American Sociological Review, 62, 2, 209-1 7.

Accepted 6July 20I7; first published online 22 August 2017

Address for correspondence:

Katja Möhring,

Department of Sociology,

University of Mannheim,

D-68131 Mannheim, Germany

E-mail: moehring@uni-mannheim.de 